\title{
A Telecollaboration Project on Giving Online Peer Feedback: Implementing a Multilateral Virtual Exchange During a Pandemic
}

\author{
Michael Joseph Ennis ${ }^{1}$, Massimo Verzella ${ }^{2}$, Silvia \\ Montanari ${ }^{1}$, Agnieszka M. Sendur ${ }^{3}$, Marieta Simeonova \\ Pissarro $^{4}$, Staci Kaiser ${ }^{4}$, Andrew Wimhurst ${ }^{1}$ \\ ${ }^{1}$ Free University of Bozen-Bolzano, Bozen-Bolzano, Italy \\ ${ }^{2}$ Penn State Erie the Behrend College, Erie, Pennsylvania, USA \\ ${ }^{3}$ Andrzej Frycz Modrzewski Krakow University, Krakow, Poland \\ ${ }^{4}$ University of Nevada Las Vegas, Las Vegas, Nevada, USA
}

\begin{abstract}
Correspondence concerning this article should be addressed to Michael Joseph Ennis, Language Centre Free University of Bozen-Bolzano Universitäatsplatz 1 - Piazza Università, 1 I - 39100 Bozen-Bolzano. E-mail:mennis@unibz.it
\end{abstract}

\begin{abstract}
Telecollaboration, also called virtual exchange or online intercultural exchange, is a form of collaborative learning whereby language learners in different locations engage in computer-mediated communication to complete tasks online. There is ample evidence that telecollaboration promotes the acquisition of language skills, intercultural competence, and digital literacies. Challenges faced implementing virtual exchanges include differences in time zones, learning objectives, academic calendars, and cultural attitudes. The present article describes a case of a multilateral telecollaboration project based on the facilitated dialogue model involving four institutions-two in Europe and two in the United States-that was designed to prepare students for the experience of giving online peer feedback on collaborative writing assignments. Our initial goal was to explore the challenges students would face and the benefits they would receive from a complex telecollaboration project involving multiple institutions and two task sequences: 1) input and reflection on giving and receiving peer feedback, 2) completion of the collaborative writing task to be peer reviewed. However, new challenges and opportunities emerged after the switch to emergency e-learning and remote teaching during the Covid-19 pandemic. Relying upon multiple data sources-including correspondence, observations, class discussions, surveys, reflective writing, and information stored in virtual learning environments-our methods of data collection involved convenience sampling, while data analysis was predominantly descriptive. Our results demonstrate that even during a global pandemic, students and instructors face similar logistical challenges and reap similar benefits as has been reported in the literature. Yet our experience also reveals the resiliency of telecollaboration in the face of extreme disruption as well as the potential to exploit virtual exchange to develop learning strategies-such as methods for giving and receiving peer feedback-and meta-awareness of how language is used in the real-world-such as the implications of English as a lingua franca.
\end{abstract}

Keywords: telecollaboration/virtual exchange, facilitated dialogue model, English as a lingua franca (ELF), peer feedback, collaborative writing, remote teaching, emergency e-learning

\section{Introduction}

A key goal of higher education in the $21^{\text {st }}$ Century is to prepare students to succeed in diverse, global, and interdependent societies. Mission statements of most international universities thus promise to help students become global citizens. Becoming a global citizen entails the development of the ability to communicate and collaborate across cultures, including proficiency in foreign languages, communication skills, and intercultural competence (Crowther et al., 2000; Beelen \& Jones, 2015), which can be defined as "the ability to think and act in interculturally appropriate ways" (Hammer et al., 2003, p. 422). Traditionally, mobility programs have been viewed as the gold standard for fostering such skills, but too few students can afford the costs of trips abroad 
and study places are limited. ${ }^{1}$ In addition, the covid-19 pandemic has provided further proof that universities need to offer students alternative opportunities to interact and collaborate with peers from foreign countries.

One alternative model to internationalization abroad is internationalization-at-home (IaH), defined as oncampus programs and initiatives that connect students from different cultural backgrounds. IaH initiatives can engage all students and, in general, they appear to be more sustainable compared to traditional study abroad. Some scholars have demonstrated that IaH can be even more effective than study abroad in helping students develop their ability to communicate across cultures (Soria \& Troisi, 2014).

Among the various IaH initiatives that can be organized by university instructors, telecollaboration stands out as the one that has gained most traction in the last twenty years. Telecollaboration, also known as virtual exchange or online intercultural exchange, can be defined as any activity in which language learners from different institutions-typically based in different countries-collaborate to complete online tasks or projects with the aid of computer-mediated communication (Dooly, 2008; Guth \& Helm, 2010; O'Dowd, 2006). In the context of language education, telecollaboration combines computer assisted language learning with social constructivist theories (Warschauer, 2005). In addition to promoting language acquisition, scholarship has suggested that telecollaboration can be exploited to foster the development of intercultural communicative competence (Dooly, 2008; Guth \& Helm, 2010; O’Dowd, 2006, 2007; O’Dowd \& Lewis, 2016; Ware \& Kramsch, 2005) and digital literacies (Guth \& Helm, 2010, 2011). Whereas early models of telecollaboration, such as e-tandem (Cziko, 2004; O’Rourke, 2007), focused on giving language learners the opportunity to partner with "native speakers," more recent schemes are based on the facilitated dialogue and lingua franca models, whereby trained educators facilitate online exchange involving "non-native speakers" (Helm, 2016, 2017). ${ }^{2}$

Another benefit of telecollaboration is that such projects reproduce the complex conditions under which professionals increasingly work today in cross-cultural virtual teams (Maylath et al., 2013). Lack of alignment in the organization of curricula, class schedules, attendance policies, and learning outcomes results in different levels of commitment on the part of students and several other problems that instructors and participants must resolve through constant mediation. In particular, multilateral telecollaboration projects-i.e., those that involve three or more partner universities - are characterized by complexity (Maylath et al., 2013; Arnó Macià et al., 2013). Instructors and students need to find ways to manage this complexity, which means negotiating divergent goals and constraints and coping with the fact that tasks are dispersed across space and time due to the application of internet communication and collaboration tools (e.g., Google Drive, e-mail, Skype, Zoom, and WhatsApp), where each tool provides specific affordances while carrying specific ideologies that motivate their use.

\section{Background}

Against this background, this article presents a case of a multilateral telecollaboration project linking seven classes taught by five instructors at two universities in Europe and two universities in the United States. The project was conceived, in part, as a Transnational Erasmus+ Virtual Exchange Project (TEP) under the auspices of UNICollaboration. ${ }^{3}$ UNICollaboration is an academic organization that offers a hub for virtual exchange practitioners (O'Dowd, 2018). The driving force behind the UNIcollboration initiative is the INTENT (Integrating Telecollaborative Networks into Foreign Language Higher Education) consortium, whose members published a position paper in $2014^{4}$ that defines virtual exchange as "technology-enabled, sustained, people to people education programs" (sect. 1). Virtual exchange initiatives link students from partner classes in geographically distant locations so that they can collaborate in projects that "foster intercultural dialogue, the development of digital and critical literacies as well as foreign language skills" (sect. 1). Importantly, these programs help students improve cross-cultural understanding and their ability to collaborate as part of diverse teams (sect. 3). The UNIcollboration online platform allows instructors to find project partners for different forms of virtual exchange.

\footnotetext{
See https://www.iie.org/Why-IIE/Announcements/2017/11/2017-11-13-Open-Doors-2017-Executive-Summary

2 We use the terms "native speaker" and "non-native" speaker in full awareness of the debates surrounding their use. In fact, we challenged students' notions of these concepts throughout our project. However, these terms are widely used in the telecollaboration literature. Furthermore, in the context of our study there was a clear distinction between L1 users of English and L2 learners.

3 For more information, see https://www.unicollaboration.org/

4 See https://www.unicollaboration.org/wp-content/uploads/2016/06/Position-paper_1.pdf
} 
Our telecollaboration project involved a TEP component, although our multilateral partnerships were formed before connecting with UNICollaboration. Specifically, our project linked the following courses offered at four universities:

- One English as a foreign language (EFL) course offered by the Language Centre of the Free University of Bozen-Bolzano (unibz);

- Two EFL/English for specific purposes (ESP) courses offered by the Language Centre at Andrzej Frycz Modrzewski Krakow University (AFMKU);

- Two ESL bridge program courses offered by the English Language Centre at the University of Las Vegas Nevada (UNLV);

- One course on rhetoric and composition and a second course on writing for the web offered by the English program at Penn State Erie, The Behrend College (PSB).

The initial impetus for our project came from the unibz Language Centre, which had been seeking virtual exchange opportunities. During recent collaborations on unrelated projects with a founding member of UNICollaboration and two co-authors of the present study, the English language coordinator at unibz was exposed to a concise overview of the effectiveness of telecollaboration in fostering intercultural competence in English as a lingua franca (ELF) contexts (Helm, 2017) as well as an example of a trans-Atlantic virtual exchange involving collaborative writing with feedback from native-speaker peers (Verzella and Sendur, 2019). A similar project seemed to be an ideal solution at unibz, a trilingual university where English primarily serves as a medium of instruction and a lingua franca between L1 speakers of German and Italian, but where students have few opportunities to practice writing in English and few opportunities to interact with native speakers of English outside the EFL classroom.

UNICollaboration encourages TEP coordinators to adopt a facilitated dialogue model of virtual exchange (see Helm, 2016, 2017), whereby the participants-who predominantly come from different cultural and linguistic backgrounds-use the English language as a lingua franca (Jenkins, 2007, 2015; Seidlhofer, 2011). The aim of this model of telecollaboration-also called the facilitator-led model of virtual exchange (O'Dowd et al., 2019, p. 5), or the dialogic model of telecollaboration (Helm, 2013, p. 36)-is to help students develop critical thinking skills, audience awareness, intercultural sensitivity, and digital literacies with the aid of trained facilitators (Helm, 2013, p. 36; Helm, 2017, p. 138). The facilitators moderate synchronous and asynchronous interactions between cohorts of students, and help the students construct identities, establish relationships, and manage and mediate miscommunications and misunderstandings. In the remainder of this paper, we will therefore refer to the partners who designed and implemented the TEP module as "facilitators", while the partners who were responsible for the design and implementation of the seven courses at the four institutions will be called "instructors".

\section{Goals and Research Questions}

The aim of our project was to pilot a novel form of telecollaboration involving four institutions located in three countries. This article should therefore be read as a case which might inform the design and implementation of multilateral virtual exchanges. During a previous project, two of our partners, Verzella and Sendur (2019), reconfirmed the effectiveness of collaborative writing (Mousten et al., 2018; Mulligan \& Garafolo, 2001; Saunders, 1989; Storch, 2005, 2011) in language education, but found, among other things, that students require input from their instructors when peer reviewing or being peer reviewed across national boundaries via the internet, especially when native speakers are commenting on the writing of L2 learners. Building upon their experience, we agreed that our project would likewise involve collaborative writing tasks that would be peer reviewed, but that the TEP facilitators would first offer students the opportunity to discuss and reflect on norms and strategies for giving and receiving peer feedback (Baker-Smemoe, 2018; Rollinson, 2005).

Our initial goal was to explore the challenges and benefits of a multilateral telecollaboration project involving two parallel task sequences, one in which students participated in a TEP that prepared them for the experience of giving and receiving feedback from their foreign peers, and a second which required students to collaboratively compose multimodal texts that would subsequently be peer reviewed. As partner institutions began to grapple with the corona virus, a secondary goal became to explore the feasibility of such a complex design amid a global pandemic. 
At its onset our study aimed to answer the following research questions:

RQ1: What challenges would our students encounter as they collaborated with peers on a digital writing project that culminated in peer feedback from speakers with varying levels of proficiency in English?

RQ2: What benefits would our students gain from this experience, in particular from their discussions and reflections on giving and receiving peer feedback?

The story of any multilateral telecollaboration project cannot be easily constrained within the conventions of technical reports. Nevertheless, the remainder of the paper will attempt to follow the IMRaD structure to provide anchoring for a research project that also had to cope with the tidal wave of Covid-19 disruptions. Clearly, the pandemic added another level of complexity and "messiness" to our telecollaboration project. In addition to negotiating divergent needs and expectations across classes and institutions (e.g., different course syllabi and academic calendars) and in addition to managing intercultural communication and online interactions, course instructors and online facilitators soon found themselves dealing with unexpected difficulties. Our experience, however, demonstrates the adaptability and sustainability of carefully planned telecollaboration projects, even in the face of a global pandemic which shuttered academic institutions and entire nations.

Although we view the design and implementation of our project to be the products of a complex negotiation process, and as such to be research results in their own right, the methods section that follows will illustrate these aspects as well as our data collection procedures. The subsequent sections present findings related to student engagement, learning outcomes, and the reflections of the authors and the students as pertain to the value this experience has for the teaching of EFL/ESL and English composition. The conclusion aims to consolidate findings across institutions and comment on the implications for planning and implementing multilateral virtual exchanges.

\section{Methodology}

\section{Participants}

Six students from unibz participated in the project. At unibz English serves as one of three languages of instruction as well as a lingua franca between L1 speakers of German and/or Italian but is taught and learned as a foreign language (see Ennis, 2015). The unibz language curriculum is structured into modules aligned to the Common European Framework of Reference for Languages (CEFR) (Council of Europe, 2001). The Language Centre generally divides each CEFR level into four forty-hour modules so students can progress through each CEFR level in a linear fashion. The telecollaboration project was integrated into a B2.2a general English module. To enroll in the course, students had to either complete an online placement test or successfully pass the B2.1b module. At unibz remote teaching/learning was mandated starting on March 10, 2020, shortly before the scheduled start date of the course on March 15.

Forty-eight students participated in the project at AFMKU. They were all enrolled in Film and TV Production Management, an English-taught Bachelor of Arts program. The class consisted of students from Poland, Ukraine, Belarus, Russia, and Turkey. To be accepted to the program, the candidates had to provide a B2 English certificate. The program in which the telecollaboration project was incorporated was English for Media Production-an EFL/ESP course aimed at developing the students' general language skills to a C1 level and equipping them with ESP skills. The project was conducted during the second semester of a two-semester course. The students were divided into two groups - of twenty-three and twenty-five students-and were taught by two instructors. Project teams were created before all university classes switched to online instruction on March 12.

Twelve students from four countries-China, South Korea, Japan, and Vietnam - participated in the project at UNLV. They were enrolled in Level 6 (Academic), the top level of the ESL Bridge Program, and had to demonstrate a B2 language proficiency level in order to enroll. The ESL Bridge Program at UNLV is a 6-level, full-time intensive English program offering 20 hours of ESL instruction per week in all modalities: grammar, listening and speaking, reading, writing, and ESP. On March 23, all ESL classes transitioned to remote instruction due to 
Covid-19. At that time, the international telecollaboration project became a major component of the Advanced Listening and Speaking course and the Academic Writing course, which each met for 5 hours per week for a total of 10 hours of remote instruction. These two ESL classes were taught by the same instructor.

Forty-four students from PSB participated in the project. Penn State Behrend students were enrolled in two courses: Rhetoric and Composition (RC) and Writing for the Web (WW). In preparation for the telecollaboration project, class discussions in both courses covered the challenges of writing for the global community of users of English, and the use of ELF. Students also reflected on the limits of the ideology of monolingualism (Bou Ayash, 2016) and the fact that global Englishes and ELF are often defined by their lack of conformity to standard rules (Lu \& Horner, 2013). As opposed to the ideology of monolingualism, translingual theory (Horner et al. 2011; Horner et al., 2011) argues that what matters in composition is adaptability and flexibility in language use, the same adaptability that writers must have across modes, media, genres, and contexts (Donahue, 2018, p. 206). PSB switched to remote teaching on March 16.

\section{The Collaborative Writing Project: Creating and Assessing Websites}

Our initial plan was to ask all participating EFL/ESL students to collaborate across institutions (synchronously and asynchronously) in the creation of a website that would contain a range of multimodal texts. However, we immediately encountered some of the challenges identified by O'Dowd and Ritter (2006) at the class and socioinstitutional levels of telecollaboration. These challenges were accentuated by the number of courses, instructors, and institutions participating in the project. Each of the partners was fully committed to realizing the project, but course syllabi were fixed and largely inflexible, and semester schedules-start dates, end dates, and breaks-were not aligned.

In response, we decided that it would be implausible to require students based in different countries to submit an online project together. Instead, we reached a consensus to grant each instructor the flexibility to integrate the project into their respective contexts, thereby accommodating for divergent curricula, syllabi, teaching styles, and learner needs. The tasks assigned to students enrolled at the four universities were as follows:

- Unibz students had to create a website which aimed to persuade UNLV and AFMKU students to study at unibz. As will be discussed in the Results section below, the course instructor substituted another instructor on short notice after the switch to emergency remote teaching. As a result, the instructor did not have sufficient time to integrate the project into the existing syllabus and instructions were rather vague. The project was in effect treated as optional homework which students completed autonomously.

- AFMKU students had to create a website which aimed to persuade visitors to study Film and Media Production Management at AFMKU. The websites were to include three obligatory pages: a video presenting the University or the course, a film review, and a film and media production glossary, as well as some optional elements students could choose. It was stressed that the task was to be done collaboratively and all participants were responsible for the final results.

- UNLV students also had to create a website. Since many ESL Bridge graduates plan to transition into a Hospitality major at UNLV, their websites focused on persuading their audience to select Las Vegas for their next vacation destination. The websites featured a 700-800-word persuasive essay, a 300-500word written article, and a 3-5-minute student-generated video.

- All PSB students were native speakers of English. Those enrolled in Writing for the Web (organized in eight groups) had to browse the websites produced by their peers at AFMKU and offer suggestions using a feedback form created by the two instructors. The students enrolled in the Rhetoric and Composition (RC) course had to offer comments on the three websites developed by UNLV students during whole class discussions conducted in three class meetings. This alternative method for feedback was chosen because there were only three websites to evaluate for the 20 students enrolled in the RC course. Second, the instructors were interested in seeing what observations the RC students would offer once they compared the three websites.

The capstone of this task sequence of the telecollaboration was peer feedback: It was planned that drafts of each website would undergo two rounds of peer assessment: first by fellow EFL/ESL learners at unibz, AFMKU, and UNLV and then by the native-speaker peers at PSB. All students negotiated specific rules for providing 
constructive peer feedback. Unibz, AFMKU, and UNLV students were prepared for this experience during the second task sequence mediated via the TEP, while PSB students were prepared by their instructor.

\section{The TEP: Preparing to Give and Receive Feedback}

The purpose of the TEP-which was pre-approved and fully supported by UNICollaboration-was to prepare the EFL students for the experience of giving and receiving online feedback from peers whom they would likely never meet face-to-face. Initially, we discussed the possibility of requiring all students to participate in the TEP and using the same virtual learning environment to facilitate the TEP and the submission and peer review of the websites. However, after much discussion, it was discovered that some course instructors were concerned about overburdening their students with additional tasks and online platforms. Whereas a collaborative writing task could be easily integrated into a course syllabus, the training on peer feedback was perceived by the instructors as "extra work" for their students. In addition, all course instructors were already using a VLE and other digital tools in their courses. Ultimately, it was decided that only the EFL learners would participate in the TEP, not the native-speaker students from PSB. Furthermore, TEP participation was optional for the AFMKU students, but mandatory for the unibz and UNLV students, at the discretion of the respective instructors. Thus, while the TEP was designed and administered by the TEP facilitators, the website project and the peer review process were managed separately by the course instructors, primarily via each institution's own VLE and via email.

It was agreed that for the EFL students, the sequence of tasks that comprised the TEP would be assigned as approximately eight hours of autonomous homework, which in the case of AFMKU meant "optional" homework. While completion grades were awarded at the discretion of the instructors, all students who successfully completed the TEP were eligible to receive an open badge $e^{5}$ through UNICollaboration.

The decision to treat the TEP and the website task separately added another layer of complexity to our project. The alignment of the two strands of the project-the creation and peer assessment of the websites, on the one hand, and the TEP activities, on the other hand-is outlined in Appendix 1, whereas the alignment of the project to the different semester schedules is presented in Appendix 2.

\section{Instructional Design of the TEP}

The TEP component of our virtual exchange was designed and implemented by three facilitators based at unibz. These facilitators were required to complete a training course on the UNICollaboration platform before planning their own TEP. This hands-on experience introduced the facilitators, both in form and in content, to the instructional design of the facilitated dialogue model. Based on this training, the facilitators created the task sequence and then moderated online discussions over a four-week period.

The TEP was delivered fully online using the Moodle platform of UNICollaboration. The instructional design consisted of three key components:

- The task sequence;

- The roles of the facilitators; and

- The digital tools employed to facilitate interaction.

The task sequence included three task types commonly adopted in virtual exchanges (O'Dowd \& Waire, 2009; Guth \& Helm, 2011): information exchange tasks, comparison and analysis tasks, and collaboration tasks. The sequence was segmented into five sessions (see Appendix 1). Each session consisted of a main theme or discussion topic and required students, who were divided into three mixed work groups, to engage in informal asynchronous dialogues with their peers and facilitators (O'Dowd \& Waire, 2009, p. 175). The five sessions were loosely aligned with Salmon's (2013) 5-stage model of teaching and learning online: "access and motivation, online socialization, information exchange, knowledge construction, and development" (p. 46), which offered facilitators clear guidelines to follow (Dooly, 2008, p. 65).

\footnotetext{
${ }_{5}$ For details, see: https://www.unicollaboration.org/index.php/2020/02/20/open-badges-for-virtual-exchange/
} 
Following the guidelines of the facilitated dialogue model (Helm, 2013, p. 36), the main task of the facilitators during the implementation phase was to encourage students to participate actively in all tasks, especially the asynchronous and synchronous dialogues. To this end, facilitators attempted to establish a positive rapport with and among students within the VLE, engage students in the discussion forums, and cautiously intervene at first sight of miscommunication or conflict.

The primary digital tool utilized was Moodle's discussion board activity, mainly because of its asynchronous nature, which has the advantage of being space- and time-independent, giving students extra time to reflect and respond to peers (Helm, 2013, p. 30; Salmon, 2011, p. 16). Moreover, discussion boards can host a variety of learning activities, including links to readings and videos, which accommodate a broad range of learner preferences and specific learning differences in processing information, by combining textual and visual modes of communication to encourage encoding (Paivio, 1986).

\section{Implementation of the TEP}

The TEP task sequence was designed so that each session built upon the previous in preparing the students for giving and receiving online peer feedback. Each session consisted of a warm-up discussion board activity which served as an ice breaker and advance organizer. This was followed by a series of activities, mostly discussion boards, which required students to share experiences, opinions, and interpretations in response to multimodal input related to giving and receiving feedback online. To support intercultural learning, students were urged to reflect upon and respond to the discussion posts of their peers and the constructive feedback and commentary provided by the facilitators.

The first session (see Appendix 1) orientated the students to the platform, challenged their existing (auto) stereotypes, introduced their facilitators, supported them in constructing online identities, and established some netiquette for the purposes of the TEP (Guth \& Helm, 2011, p. 45; Salmon, 2013). In session two, students reflected on the role of feedback in language learning and shared their own diverse experiences, thoughts, and preferences regarding teacher-led feedback versus peer feedback, in an attempt to emphasize the validity and importance of the latter. In these first two sessions the facilitators attempted to make students feel welcome and provided many scaffolds and affordances to encourage participation.

In session three, students were asked to compare online feedback with face-to-face feedback. At this stage the facilitators attempted to focus students' attention on the distinguishing features of and useful strategies for online communication (Dooly, 2008, p. 57), not only to prepare them for the experience of giving and receiving feedback from their peers via online tools and platforms, but also to mitigate misunderstandings and ease online communication among students during the TEP itself.

In session four, the students were required to consolidate the input and ideas they encountered during the first three sessions as they collaboratively constructed ten rules for giving feedback in the form of a wiki. These rules would then inform the first round of peer feedback on the first draft of the websites they were preparing contemporaneously (Appendices 1 and 2). The facilitators actively encouraged participating students to contribute to constructing these rules and commented on the final products.

In the final session, students were required to reflect upon different perspectives on English as a lingua franca and its implications for receiving feedback from native speakers, prior to submitting a second draft of their websites for feedback from their native-speaker peers at PSB (see Appendix 1). The implied upshot was that such feedback should ultimately focus on their goals as learners of English and the contexts in which they (will) actually use English. Especially during this set of tasks, the facilitators aimed to enhance reflection and promote metacognition.

After sessions four and five, students participated in synchronous sessions offered by UNICollaboration. These sessions were held via Zoom and served as a debriefing after each round of peer feedback, so that students could reflect further upon the experience. 


\section{Data Collection}

Students were informed that their instructors would be collecting data to evaluate the effectiveness of the project and all students who participated in the TEP gave informed consent for data stored in the UNICollaboration Moodle platform to be used for research purposes. The research team therefore had many sources of data at their disposal.

All course instructors made observations and kept notes to document students' progress as well as their questions and reflections about virtual exchange and peer feedback. In addition, instructors conducted class discussions before, during, and/or after the telecollaboration. Two instructors (AFMKU and UNLV) conducted separate surveys ( $n=17$ and $n=12$, respectively), while UNLV students also reflected on the entire experience in a follow-up writing assignment $(n=12)$ where they wrote a persuasive text on whether or not future ESL Bridge students should participate in similar telecollaboration projects. Two final sources of data were the email exchanges and conference calls that facilitators and instructors had throughout the project.

Regarding the TEP, data was primarily collected via the platforms used for that component of the project. More specifically, there were four sources of data during the TEP: the observations of the unibz facilitators during asynchronous interactions with and between students via Moodle discussion forums; the observations of the UNICollaboration facilitators made during the facilitated dialogues conducted synchronously via Zoom; a final assessment for which students were asked to write a short essay to describe the most important lesson they learned from participating in the TEP $(n=18)$; and a survey administered to all TEP participants by UNICollaboration ( $n=17)$. The use of Moodle and Zoom for the TEP also enabled unibz facilitators to quantify student engagement via user logs, task submissions, and the awarding of open badges.

Data collection could therefore best be described as convenience sampling and data analysis is predominantly descriptive in nature.

\section{Results and Discussion}

As Table 1 illustrates, we observed a drop in student participation during our project. This was in part due to the expected decline in student motivation over time and in part because of the effects of the pandemic. The many factors which contributed to students dropping out of the TEP, their website projects, or even their English courses will be discussed in the subsequent sections. At this point it is important to note that that the proportion of AFMKU students who completed the TEP was much lower than the proportion of unibz and UNLV students. This was clearly because TEP participation was optional for the AFMKU courses and mandatory for the unibz and UNLV courses.

Table 1

Participation in the Project

\begin{tabular}{|c|c|c|c|c|c|c|c|}
\hline $\begin{array}{l}\text { Participating } \\
\text { Institutions }\end{array}$ & $\begin{array}{l}\text { Participating } \\
\text { Courses }\end{array}$ & $\begin{array}{l}\text { Participating } \\
\text { Students }\end{array}$ & $\begin{array}{c}\text { Website } \\
\text { Participants }\end{array}$ & $\begin{array}{c}\text { TEP } \\
\text { Enrollments }\end{array}$ & $\begin{array}{c}\text { Synchronous } \\
\text { Meeting } 1\end{array}$ & $\begin{array}{c}\text { Synchronous } \\
\text { Meeting } 2\end{array}$ & $\begin{array}{c}\text { Open } \\
\text { Badges }\end{array}$ \\
\hline AFMKU & 2 & 48 & 43 & 34 & 18 & 1 & 10 \\
\hline PSB & 2 & 44 & 44 & N/A & N/A & N/A & N/A \\
\hline unibz & 1 & 6 & 5 & 6 & 5 & 4 & 3 \\
\hline UNLV & 2 & 12 & 12 & 12 & 11 & 0 & 11 \\
\hline TOTAL & 7 & 110 & 104 & 52 & 34 & 5 & 24 \\
\hline
\end{tabular}

\section{Challenges Encountered}

Many of the challenges observed during our project are universally reported by telecollaboration organizers and participants (see O'Dowd \& Ritter, 2006). Although these challenges were exacerbated in our case by the pandemic, some of them would have been encountered in some measure even if everything had proceeded according to plan. For example, comments collected in surveys and class discussions demonstrated that the 
students' main source of dissatisfaction was having to wait too long before receiving replies to their posts during the TEP and before receiving peer feedback on their websites. The lag in replies and feedback was a result of the partner institutions following different academic calendars (see Appendix 2). Facilitators and instructors attempted to compensate for these differences in the careful alignment of the telecollaboration schedule, which resulted in tight deadlines and made students feel that the time available to complete tasks was often insufficient. The switch to emergency remote teaching merely made the deadlines more difficult to maintain.

In general, group work presented challenges due to normal group dynamics or the simple fact that some writing teams were perhaps too large, especially at AFMKU, where the average was six students per group, in comparison to three to five per group at unibz and UNLV. In response to open-ended questions included in the survey administered at AFMKU, some students revealed that they did not enjoy collaborative writing, explaining that it did not allow them to express their personal viewpoints, and instead demanded a consensus. Students asserted that collaborative writing required more time and effort, which made it more difficult to work toward strict deadlines.

There is an important caveat to students' criticisms of heavy workloads and tight deadlines. Many of the students who complained about these issues added that they thought the tasks would not have been so cumbersome if not for the switch to online classes, which made the project extremely time-consuming. In fact, students from all participating universities mentioned problems with internet connection and asynchronous collaboration, which hindered online teamwork on the website and participation in the TEP.

Perceptions of the quality of the peer feedback also varied. PSB students offered plenty of feedback on website design and the use of multimedia, whereas students from AFMKU and UNLV expected a stronger focus on the linguistic aspects of their writing, such as grammar, collocations and colligations, and register and style. These issues were a problem of differing expectations. European students, who were non-native speakers of English, seemed to rely on native speakers in the US as language experts, but the native speakers hesitated to play this role because they did not feel they had a good grasp of English grammar themselves.

Regarding the TEP, the time differences between participants' countries and the variations in the academic calendars among participating institutions posed logistical challenges. For example, the UNLV students completed the first two modules of the TEP one week in advance, as the due dates for those sessions were scheduled during UNLV's Spring Break (see Appendix 2). One UNLV student lamented, "waiting for the other people in [the] group to reply [to] the topics... made [me] late for the deadline." The AFMKU students who opted to participate in the TEP brought up the time commitment required to complete all tasks. In their final essay during the TEP, some students described the necessity of responding to other students' comments as "forced"; they felt they had to do it just for the sake of completing the task and not because of a real need to express their opinions. The TEP facilitators noticed this in the curtness of some of the students' posts to the discussion forums.

The TEP facilitators also remarked that the separate treatment of the TEP and the website project made the projects seem disconnected from one another and made them feel somewhat excluded from the website project, in that they gained access to the final products but not the first and second drafts or the feedback provided by peers. As such, they never really experienced the fruits of their labor.

Originally, only the TEP and the peer feedback were to be completed online. The respective courses and the website projects were expected to be completed as face-to-face classroom activities and/or homework. However, as the partner institutions closed their doors to face-to-face teaching, all aspects of the courses were soon conducted virtually. It is therefore impossible to describe and evaluate this project adequately without careful reflection on the effects of emergency remote teaching. The next section will present the main challenges this project faced during the first months of the pandemic.

\section{Disruptions Caused by the Covid-19 Pandemic}

Successful completion of the project required regular communication between partners, and there were, of course, many expected challenges that could be anticipated and managed on a case-by-case basis, such as issues with technology, different time zones, or miscommunication and conflict between students (O'Dowd \& Ritter, 
2006). But the greatest challenge that emerged during our project was the unexpected disruption to higher education caused by the Covid-19 pandemic in the Spring of 2020. As has been reported extensively throughout the pandemic, our experience provides further evidence of the fatigue and digital overwhelm associated with emergency e-learning (e.g., Gacs et al., 2020; Murphy, 2020). In addition, the sudden absence of face-to-face interaction between classmates and between the instructors and their students at times inhibited the communication of objectives and instructions, made it more difficult to evaluate student progress, and impacted learner motivation to participate in ungraded activities.

The immense shock to the lives of students-some of whom found themselves isolated in a foreign city or country, forced to return home, sometimes without textbooks and personal devices, or experiencing other ramifications in their personal lives-resulted in some students finding refuge in telecollaboration and others prioritizing more important personal matters. The instructors and facilitators observed a steady decline in the number of active participants as the pandemic-and the emergency responses thereto-spread from Italy, to Poland, to Pennsylvania, to Nevada.

As each course consecutively switched to emergency remote teaching, and students returned to their homes in other cities or countries, the role of the TEP within the telecollaboration project seemed to get muddled in the onslaught of instructions and platforms, and the facilitators had to clarify frequently. Even our UNICollaboration contacts and facilitators and the instructors of the participating courses often asked the unibz facilitators for reminders and clarifications. These observations coincided with a decline in active participation in TEP activities from session to session (see Table 1).

At unibz the switch to remote teaching/learning due to Covid-19 shortly before the start date of the course resulted in far fewer enrolled students than had been expected, a one-week delay in the course start date (see Appendix 2), and a substitution of the instructor before the course began. The unibz students therefore initiated the TEP and the website project one week after their peers at UNLV and AFMKU, and they were forced to recuperate the missing TEP session during their first week of lesson. In addition, the new instructor had not participated in the planning of the telecollaboration and was not privy to prior discussions of how the project would be integrated into existing syllabi by the other instructors. Whereas the UNLV and AFMKU instructors adapted composition tasks already included on their course syllabi into subtasks of the website project, unibz students were merely asked to work in groups to design the website as an additional ungraded assignment, without indications of text types or length. Thus, for the unibz students, completing the project did not require them to produce the specific genres that were taught in the course. The instructor of the course doubted the pedagogical value of the resulting website, as students tended to focus on the visual features of their website while neglecting written text. In addition, unibz students were only able to participate in the first round of peer feedback with AMFKU students, well after the indicated deadline, and never interacted with PSB students.

Further complications, specifically for PSB students, were due to the project timeline. PSB students started to work three weeks before the end of the semester, when they were also focusing on their own final projects. At that moment, all Penn State campuses had already switched to remote-only instruction and some students had to cope with various logistic issues. Some of them could not access their dorm rooms where they kept books and computers; others had problems with their devices and other hardware; and yet others did not have a quiet study space available to them.

Many students, especially at unibz, AFMKU, and UNLV had to deal with travel restrictions which either made it difficult to return to their home countries or resulted in them being stranded in a foreign country during a lockdown. Although none mentioned it explicitly, UNLV students from Asia had to cope with negative stereotypes prevalent in the American news media and on social media.

\section{Benefits Gained}

Notwithstanding the challenges detailed above, responses to surveys and reflection tasks as well as instructor observations during class discussions suggested that a high percentage of students perceived the overall learning experience as satisfying and in line with their expectations. A key question of the AFMKU questionnaire, for example, asked students to evaluate specific elements of the project on a five-point scale, where 1 meant "didn't like it" and 5 meant "liked it very much". The website project, which included creating the websites, revising 
them based on peer feedback, and providing feedback to the foreign partners, received an average of 3.5. Giving peer feedback in the telecollaboration project was something the students enjoyed the most, with a mean score of 4.5. The AMFKU students who opted to participate in the TEP also gave that experience a high rating ( 4.3 out of 5$)$.

At unibz, all five regularly attending students passed the course. Despite the challenges faced implementing the website projects, all five contributed to the website and all five enrolled in the TEP. Four of five students participated in both synchronous meetings and three of five completed enough of the TEP to receive an open badge (see Table 1). In class discussions, students expressed positive attitudes toward both the website project and the TEP component. In particular, students stressed the value of meeting the facilitators and foreign students online during the initial period of the lockdown in Italy.

At UNLV, the instructor and students were very satisfied with their participation in this project. In their follow-up writing task, ten of the twelve UNLV students shared that they would recommend such telecollaborations for future ESL Bridge students because of the potential benefits: improved critical thinking, communication, and digital literacy skills and enhanced intercultural awareness and competency. One UNLV student noted, "Simultaneously, giving and receiving peer feedback from websites have facilitated the development of my ability to evaluate and observe ideas." UNLV students also appreciated the "different cultures, languages, ... [and] group work ... [through] shar[ing] all group members' ideas and put[ting] together the website, essay, article, and video." As another student concluded,

What I have learned is very worthy to me, because I may encounter more difficult tasks in the future, and the experience I have accumulated may come into use. I absolutely recommend the next Bridge class [participate] in this project, because we can learn many contents which cannot be learned in class, such as creat[ing] website[s] . . . communicat[ing] with different students in the world, [and] learn[ing] about their culture, their education and their life. In the process, we can practice our skills and improve our ability. This is a rare opportunity.

Receiving feedback during this project benefited students in terms of immediacy and validity (Hattie \& Timperley, 2007; Wiggins, 2012) because the rounds of feedback followed directly after the websites were completed, which kept the students focused on the project. One UNLV student felt that such sequencing of tasks facilitated collaborative revision: "[O]nce we got the feedback, no matter positive or negative, we just revised immediately until all members [were] satisfied.” Moreover, having an actual audience of peers and receiving feedback from the target audience made the writing process authentic and purposeful. The students were better able to grasp the rhetorical concepts of audience, purpose, and tone as the comments were coming directly from their audience and peers, not simply from their instructor.

PSB students also took away some key lessons from the project. A key problem of telecollaboration projects is that "native" speakers are frequently (implicitly or explicitly) presented as the "language experts" whereas "non-native" speakers are reductively presented as the "learners" who needexposure to "native English" (Verzella et al., 2021b). Intercultural communication can never be conceived as a one-way road in which nonnative speakers who use English as a lingua franca (ELF) have to meet native speakers in their linguistic comfort zone (Verzella et al., 2021a). Native speakers must also try to understand how ELF works, how native English is only one of the varieties of English used on the world wide web, and how different cultural traditions might affect content creation, rhetorical approaches, and stylistic choices in the creation of digital content.

This presented an important learning moment for PSB students to ask questions about their role as language consultants in this project. They were not sure how to find a balance between pointing out problems related to what they perceived as ineffective rhetorical strategies or the use of non-idiomatic English, on the one hand, and praising their peers for their creative resourcefulness in the use of ELF or appreciating their use of rhetorical moves and strategies that are not always familiar to North American audiences, on the other hand.

The questions that PSB students asked about their role in the telecollaboration were addressed during class discussions that helped all students understand their role as both cautious consultants and learners. Collectively, they decided to avoid imposing native-English conventions on users of ELF. Rather, they understood their role as linguistic negotiators and cultural mediators. One of the most interesting reflections 
shared by several PSB students was that in the attempt to imitate native/idiomatic English, their peers had used language that American audiences would find confusing or inappropriate considering the communicative goals of the websites.

Based on the data collected during the TEP, we observed that most students acknowledged the many cultural differences in the conventions of online communication and attitudes toward teacher-led versus peer feedback, demonstrating enhancement of cultural awareness. The writing task assigned at the end of the TEP revealed that students had indeed reflected on giving and receiving peer feedback via the internet, which changed their opinions about the inherent value of feedback from peers, as opposed to from teachers, and changed their online behavior when interacting across cultures.

For these reasons, and many others, we believe that our study confirms previous findings that show how telecollaboration fosters the development of language skills and intercultural communicative competence (Dooly, 2008; Guth \& Helm, 2010; O’Dowd, 2006, 2007; O’Dowd \& Lewis, 2016). The types of questions asked and the comments shared with the instructors and the TEP facilitators throughout the telecollaboration demonstrated how students developed critical thinking skills, audience awareness, and intercultural sensitivity.

\section{Conclusion}

Despite the obvious limitations of a description of a singular experience, this case study offers several important findings which might inform the design and implementation of virtual exchange, also in the absence of a global pandemic. When traditional mobility programs came to an abrupt and premature end due to the outbreak of Covid-19, this multilateral telecollaboration project went on, allowing students to connect and exchange ideas with peers in a time of forced isolation.

Telecollaboration is sustainable even when course syllabi do not overlap and semester schedules are not aligned, or are forced to change, because instructors can organize flexible projects that allow students to work at different paces and with different goals. This is not to say that our project proceeded without hitches or that our students did not experience the fatigue and digital overwhelm associated with emergency remote teaching during the pandemic, but the telecollaboration demonstrated for students and teachers alike the importance of understanding the affordances of computer mediated communication at a time when a rapid development of their digital literacies became imperative.

That the unibz group struggled to fully integrate the project into their course, that some students felt overwhelmed by the amount of work to be completed within tight deadlines, or that others felt that communication with peers abroad felt "forced" at times, indicates that telecollaboration projects must always remain open to revision and modifications and necessitate continuous communication and coordinationbetween teachers and students and across partner institutions. In future iterations, our team might consider, for instance, using a single platform for both task sequences and requiring TEP participation for all students.

As has been reported elsewhere, there is ample evidence to suggest that our students were afforded valuable opportunities to practice their English, reflect on the use of ELF in intercultural communication, understand writing as a process that requires mediation and collaboration with target audiences, and engage in intercultural learning. One novel finding of our experience is that telecollaboration can also be exploited to develop learning strategies - such as methods for giving and receiving peer feedback-and meta-awareness of communication and language in use - such as online etiquette or pragmatic strategies for effective communication in ELF.

\section{Acknowledgments}

We would like to thank all of our contacts at UNICollaboration for their input, support, and feedback at every stage of designing and implementing our the TEP component of this project, namely: Francesca Helm, Ana Beaven, Lorenza Bacino, Phillip Moecklinghoff, Rianne ten Veen, Sabine McKinnon, and Rita Koris. 


\section{Declaration of Competing Interest}

None declared.

\section{References}

Arnó Macià, E., Isohella, S., Maylath, B., Schell, T., Verzella, M., Minacori, P., Mousten, B., Musacchio, M. T., Palumbo, G., \& Vandepitte, S. (2014). Enhancing students' skills in technical writing and LSP translation through tele-collaboration projects: Teaching students in seven nations to manage complexity in multilateral international collaboration. In G. Budin, \& V. Lušicky (Eds.), Languages for special purposes in a multilingual, transcultural world. Proceedings of the 19th European Symposium on Languages for Special Purposes (pp. 249259). University of Vienna.

Baker-Smemoe, W. (2018). Peer feedback. In J. Liontas (Ed.), The TESOL encyclopedia of English language teaching (vol. 4, pp. 1-5). Wiley-Blackwell.http://dx.doi.org/10.1002/9781118784235.eelt0540

Beelen, J., Jones, E., Curaj, A., Matei, L., Pricopie, R., Salmi, J., \& Scott, P. (2015). Redefining internationalization at home. In The European higher education area (pp. 59-72). Springer.

Bou Ayash, N. (2016). Conditions of (im)possibility: Postmonolingual language representations in academic literacies. College English, 78(6), 555-577. http://www.jstor.org/stable/44075144

Council of Europe. (2001). Common European framework of reference for languages: Learning, teaching, assessment. Cambridge University Press.

Crowther, P., Joris, M., Otten, M., Nilsson, B., Teekens, H., \& Wächter, B. (2000). Internationalization at home: A position paper. European Association for International Education.

Cziko, G. (2004). Electronic tandem language learning (eTandem): A third approach to second language learning for the 21st century. CALICO Journal, 22, 25-39.http://dx.doi.org/10.1558/cj.v22i1.25-39

Donahue, C. (2018). Writing, English, and a translingual model for composition. In K. Yancey, S. Miller-Cochran, E. Wardle, \& R. Malenczyk (Eds.), Composition, rhetoric, and disciplinarity (pp. 206-224). Utah State University Press.

Dooly, M. (Ed.). (2008). Telecollaborative language learning: Moderating intercultural collaboration and language learning: A guidebook to moderating intercultural collaboration online. Peter Lang.

Ennis, M. (2015). “Do we need to know that for the exam?” Teaching English on the CLIL fault line at a trilingual university. TESOL Journal, 6(2), 358-381. http://dx.doi.org/10.1002/tesj.199

Gacs, A., Goertler, S., \& Spasova, S. (2020). Planned online language education versus crisis-prompted online language teaching: Lessons for the future. Foreign Language Annals, 53, 380-392. http://dx.doi.org/10.1111/ flan. 12460

Guth, S., \& Helm, F. (Eds.). (2010). Telecollaboration 2.0: Language, literacy and intercultural learning in the 21st Century. Peter Lang.

Guth, S., \& Helm, F. (2011). Developing multiliteracies in ELT through telecollaboration. ELT Journal, 66, 42-51. http://dx.doi.org/10.1093/elt/ccr027

Hammer, M. R., Bennett, M. J., \& Wiseman, R. (2003). Measuring intercultural sensitivity: The intercultural development inventory. International Journal of Intercultural Relations, 27(4), 421-443. https://doi. org/10.1016/S0147-1767(03)00032-4

Hattie, L., \& Timperley, H. (2007). The power of feedback. Review of Educational Research Association, 77(1), 81-112. http://dx.doi.org/10.3102/003465430298487

Helm, F. (2013). A dialogic model for telecollaboration. Bellaterra Journal of Teaching and Learning Language \& Literature, 6(2), 28-48. http://dx.doi.org/10.5565/rev/jt13.522

Helm, F. (2016). Facilitated dialogue in online intercultural exchange. In R. O’Dowd, \& T. Lewis (Eds.), Online intercultural exchange: Policy, pedagogy, practice (pp. 150-172). Routledge.

Helm, F. (2017). Two models of online intercultural exchange in higher education contexts. In M. Ennis, \& C. Riley (Eds.), Practices in intercultural language teaching and learning (pp. 131-144). Cambridge Scholars.

Horner, B., Lu, M.-Z., Royster, J., \& Trimbur J. (2011). Language difference in writing: Toward a translingual approach. College English, 73, 303-321.

Horner, B., NeCamp, S., \& Donahue, C. (2011). Toward a multilingual composition scholarship: From English only to a translingual norm. College Composition \& Communication, 63(2), 269-300. https://www.jstor.org/ stable/23131585

Jenkins, J. (2007). English as a lingua franca: Attitude and identity. Oxford University Press. 
Jenkins, J. (2015). Repositioning English and multilingualism in English as a lingua franca. Englishes in Practice, 2(3), 49-85. https://doi.org/10.1515/eip-2015-0003

Lu, M.-Z., \& Horner B. (2013). Translingual literacy, language difference, and matters of agency. College English, 75(6), 582-607. https://library.ncte.org/journals/ce/issues/v75-6/23836

Maylath, B., Vandepitte, S., Minacori, P., Isohella, S., Mousten, B., \& Humbley, J. (2013). Managing Complexity: A technical communication translation case study in multilateral international collaboration. Technical Communication Quarterly, 22(1), 67-84. https://doi.org/10.1080/10572252.2013.730967

Mousten, B., Vandepitte, S., Arnó, E., \& Maylath, B. (Eds.). (2018). Multilingual writing and pedagogical cooperation in virtual learning environments. IGI Global. https://www.igi-global.com/book/multilingual-writingpedagogical-cooperation-virtual/182887

Mulligan, C., \& Garafolo, R. (2001). A collaborative writing approach: Methodology and student assessment. The Language Teacher, 35(3), 5- 10.http://dx.doi.org/10.37546/JALTTLT35.3-1

Murphy, M. P A. (2020). Covid-19 and emergency eLearning: Consequences of the securitization of higher education for post-pandemic pedagogy. Contemporary Security Policy, 41(3), 492-505. http://dx.doi.org/10.1 080/13523260.2020.1761749

O’Dowd,R.(2006). Telecollaboration and the development ofintercultural communicative competence. Langenscheidt.

O’Dowd, R. (Ed.). (2007). Online intercultural exchange: An introduction for foreign language teachers. Multilingual Matters.

O’Dowd, R. (2018). From telecollaboration to virtual exchange: State-of-the-art and the role of UNICollaboration in moving forward. Journal of Virtual Exchange, 1, 1-23. https://doi.org/10.14705/rpnet.2018.jve.1

O’Dowd, R., \& Lewis, T. (Eds.). (2016). Online intercultural exchange: Policy, pedagogy, practice. Routledge.

O’Dowd, R., \& Ritter, M. (2006). Understanding and working with ‘failed communication' in telecollaborative exchanges. CALICO Journal, 61(2), 623-642. http://dx.doi.org/10.1558/cj.v23i3.623-642

O’Dowd, R., Shannon, S., \& Spector-Cohen, E. (2019). The role of pedagogical mentoring in virtual exchange. TESOL Quarterly, 54(1), 146-172.http://dx.doi.org/10.1002/tesq.543

O’Dowd, R., \& Waire, P. (2009). Critical issues in telecollaborative task design. Computer Assisted Language Learning, 22(2), 173-188. http://dx.doi.org/10.1080/09588220902778369

O’Rourke, B. (2007). Models of telecollaboration (1): ETandem. In R. O’Dowd (Ed.), Online intercultural exchange (pp. 41-61). Multilingual Matters.

Paivio, A. (1986). Mental representations: A dual coding approach. Oxford University Press.

Rollinson, P. (2005). Using peer feedback in the ESL writing class. ELT Journal, 59(1), 23-30. http://dx.doi. org/10.1093/elt/cci003

Salmon, G. (2011). E-moderating: The key to teaching and learning online (3rd ed.). Routledge.

Salmon, G. (2013). E-tivities: The key to active online learning (2nd ed.). Routledge.

Saunders, W. M. (1989). Collaborative writing tasks and peer interaction. International Journal of Educational Research, 13(1), 101-112. http://dx.doi.org/10.1016/0883-0355(89)90019-0

Seidlhofer, B. (2011). Understanding English as a lingua franca. Oxford University Press.

Soria, K. M., \& Troisi, J. (2014). Internationalization at home alternatives to study abroad: Implications for students' development of global, international, and intercultural competencies. Journal of Studies in International Education, 18(3), 261-280. https://doi.org/10.1177/1028315313496572

Storch, N. (2005). Collaborative writing: Product, process, and students' reflection. Journal of Second Language Writing, 14, 153-173. http://dx.doi.org/10.1016/j.jslw.2005.05.002

Storch, N. (2011). Collaborative writing in L2 contexts: Processes, outcomes, and future directions. Annual Review of Applied Linguistics, 35, 275-278. http://dx.doi.org/10.1017/S0267190511000079

Verzella, M., Arno Macia, E., \& Maylath, B. (2021a). Engineers taking a stance on technical communication: Peer review of oral presentations via the Trans-Atlantic and Pacific Project. IEEE Transactions on Professional Communication, 64(1), 66-83. http://dx.doi.org/10.1109/TPC.2021.3057246

Verzella, M., de Moraes, V., \& Destro Costa, T. (2021b). Addressing power imbalance in telecollaboration to promote attitudes of intercultural competence. Signum: Language Studies, Estudos da Linguagem, 24(1), 95101. http://dx.doi.org/10.5433/2237-4876.2021v24n1p85

Verzella, M., \& Sendur, A.M. (2019). A telecollaboration project on writing for tourism: Exploring thematic patterns in feedback exchanged by Italian, Polish, and Ukrainian students with US peer reviewers. In M.J. Ennis, \& G.M. Petrie (Eds.), Teaching English for tourism: Bridging research and praxis (pp. 170-193). Routledge. http://dx.doi.org/10.4324/9780429032141-8

Ware, P., \& Kramsch, C. (2005). Toward an intercultural stance: Teaching German and English through telecollaboration. The Modern Language Journal, 89(2), 190-205. http://dx.doi.org/10.1111/j.1540- 
ENNIS M. J., VERZELLA M., MONTANARI S., SENDUR A.M., SIMEONOVA PISSARRO M., KAISER S., WIMHURST A.

4781.2005.00274.x

Warschauer, M. (2005). Sociocultural perspectives on CALL. In J. L. Egbert, \& G. M. Petrie (Eds.), CALL research perspectives (pp. 41-52). Routledge.

Wiggins, G. (2012). Seven keys to effective feedback. Educational Leadership, 70(1), 10-16. 


\section{Appendix 1}

\section{Alignment of the Parallel Task Sequences}

\begin{tabular}{|lll|}
\hline \multicolumn{1}{|c|}{ Website Project } & Fixed Deadlines & \multicolumn{1}{c|}{ TEP } \\
\hline & March 18 & $\begin{array}{l}\text { Session 1: Ice breaker; constructing online } \\
\text { identities; Issues of online communication and } \\
\text { etiquette }\end{array}$ \\
\hline & March 20 & $\begin{array}{l}\text { Session 2: The importance of feedback in } \\
\text { language learning; teacher-led vs. student-led } \\
\text { feedback; Sharing positive and negative } \\
\text { experiences with feedback: Personal } \\
\text { expectations and cultural differences }\end{array}$ \\
\hline $\begin{array}{l}\text { Step 1: unibz, AFMKU, UNLV } \\
\text { submit first drafts }\end{array}$ & March 23 & $\begin{array}{l}\text { Session 3: Differences between face-to-face } \\
\text { and online feedback }\end{array}$ \\
\hline $\begin{array}{l}\text { Step 2: unibz, AFMKU, UNLV } \\
\text { offer peer feedback especially } \\
\text { on English and texts }\end{array}$ & April 3 & $\begin{array}{l}\text { Session 4: 10 Rules for feedback during } \\
\text { telecollaboration (student-generated list of rules } \\
\text { for giving feedback during the project) }\end{array}$ \\
\hline & April 14/15 & $\begin{array}{l}\text { First synchronous meeting: Reflecting on first } \\
\text { round of peer feedback }\end{array}$ \\
\hline $\begin{array}{l}\text { Step 3: unibz, AFMKU, UNLV } \\
\text { submit second drafts }\end{array}$ & April 17 & $\begin{array}{l}\text { Session 5: ELF and WE perspectives on } \\
\text { English as a global language and NSs and } \\
\text { NNSs: Implications for giving feedback }\end{array}$ \\
\hline $\begin{array}{l}\text { Step 4: PSB Behrend students } \\
\text { offer feedback especially on } \\
\text { rhetoric and multimodal web } \\
\text { design }\end{array}$ & April 24 & \\
\hline $\begin{array}{l}\text { Step 5: unibz, AFMKU, UNLV } \\
\text { submit final drafts }\end{array}$ & April 30 & $\begin{array}{l}\text { Assessment: Brief reflection text and survey of } \\
\text { attitudes toward website project and TEP }\end{array}$ \\
\hline evaluate formally & Varies & $\begin{array}{l}\text { Second synchronous meeting: Reflecting on } \\
\text { second round of peer feedback }\end{array}$ \\
\hline
\end{tabular}




\section{Appendix 2}

\section{Alignment of Schedules}

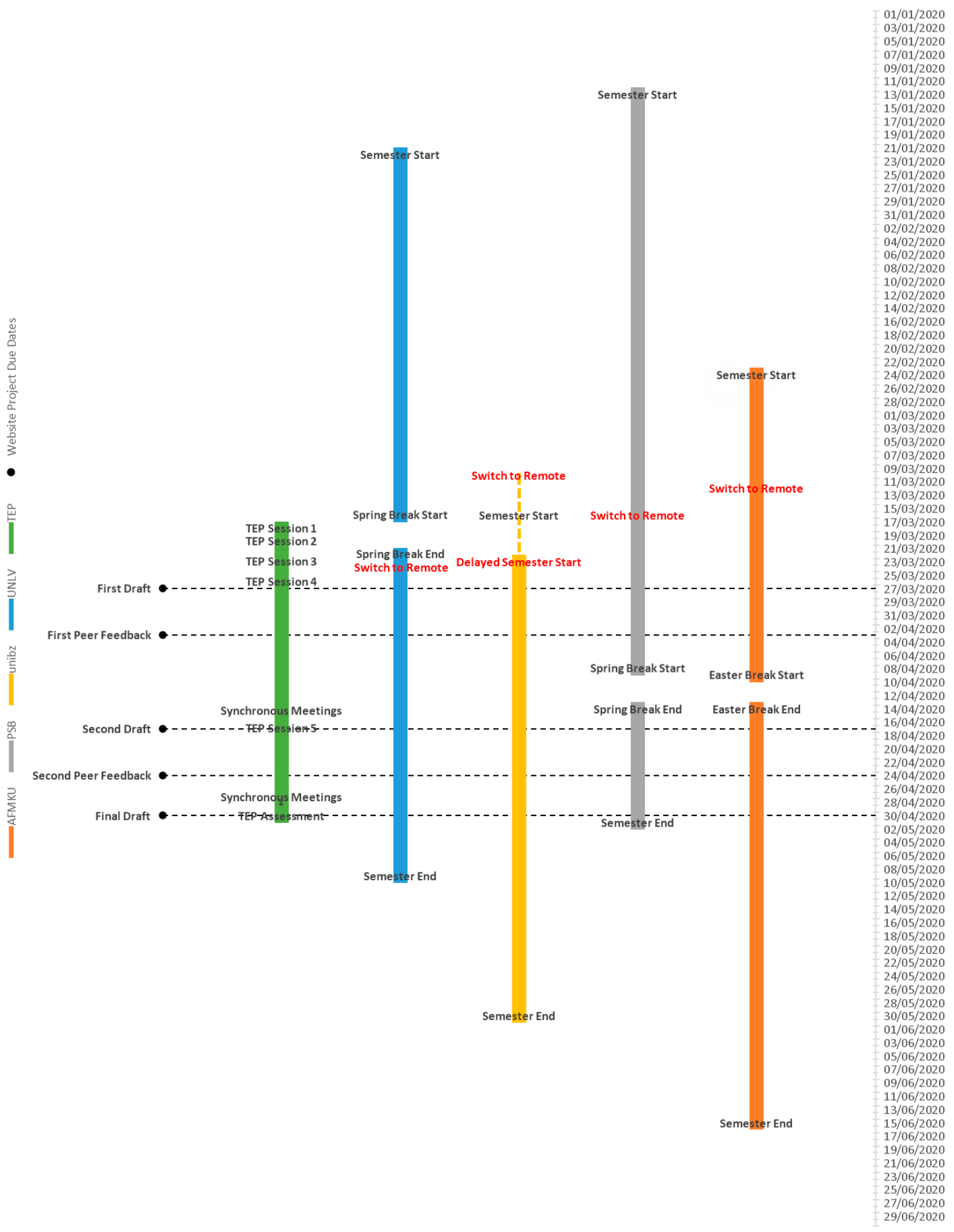

